\title{
gerpirato
}

\section{Cystic Fibrosis Mini Review}

\section{Baran Ezequiel*}

Adult Cystic Fibrosis Centre, Pulmonology, UNLP, Argentina

Received: 06 October, 2020

Accepted: 27 October, 2020

Published: 28 October, 2020

*Corresponding author: Baran Ezequiel, Adult Cystic Fibrosis Centre, Pulmonology, UNLP, 18 nro 2679, Manuel B Gonnet (1897), Buenos Aires, Argentina, Tel: 549221 5913531;

E-mail: ezebaran@gmail.com, rossifq@yahoo.com.ar

https://www.peertechz.com
Cystic Fibrosis (CF) is a complex, multisystemic disease that predominantly affects the gastrointestinal and pulmonary tracts.

The essential alteration is the production of abnormal secretions in the exocrine glands, including the salivary and sweat glands, the pancreas, the large intestine, and the tracheobronchial tree [1].

It is the most common severe autosomal recessive hereditary disease in Caucasians [2]. It is currently recognized that no group is an exception [3].

Caused by mutations in the gene encoding the transmembrane conduction regulatory protein (CFTR) on the long arm of chromosome 7 [1]. The most common mutation is the phenylalanine deletion of codon 508 (phe508del, until recently known as $\Delta$ F508) [4].

To date, around 2200 DNA sequence mutations have been described in CFTR [1,4]. The transmembrane conduction regulatory protein is a protein kinase A 5 and is expressed in many epithelial and blood cells. Although its main function is to regulate the chloride channel, it has other roles including inhibiting sodium transport, regulating adenosine triphosphate (ATP) channels, regulating intracellular vesicle transport, acidifying intracellular organelles, and inhibiting mediated chlorine channels. for calcium. In addition, it is involved in the exchange of chlorine-bicarbonate. The deficit of bicarbonate in the secretions causes less solubility and aggregation of mucins in the lumen [5,6]. Mucociliary clearance decreases and the airway is chronically colonized by bacteria.

This produces bronchiectasis, airway obstruction, and eventually respiratory failure, creating a self-perpetuating vicious cycle with inflammation and decreased clearance [7].

The incidence varies considerably, with extreme situations; in Finland it is low $1 / 25000$ and in Ireland it is high $1 / 1800$.
In our country an incidence of $1 / 3400$ to $1 / 4600$ is estimated [8]. In the world it is estimated that there are about 100,000 people affected [9]. In Latin America it is estimated between 1600 to 14000 live births. Underdiagnosis continues to be a problem. For many years it was considered an exclusive disease of pediatric age, since its diagnosis was made during the first years of life and patients died before reaching adulthood [10].

Today, the survival of patients diagnosed in childhood has improved considerably. Those born in the 1990s and diagnosed in infancy are estimated to have a life expectancy of more than 50 years. However, $5 \%$ of patients are diagnosed after the age of 16 [11].

The number of adult patients currently exceeds that of children in most developed countries [12].

The most notable factors that contributed to improving survival are early diagnosis, the development of antipseudomonal antibiotics, treatment in specialized centers, and the better nutritional status of the patients.

The diagnosis is usually made in the first six months of life; however, in recent decades the frequency of diagnosis in adult patients has increased. This is due to the possibility of detecting greater CFTR mutations, having stricter diagnostic criteria and, most importantly, the diagnostic suspicion in middle-aged patients.

Diagnostic confirmation is necessary in children and adults with clinical characteristics. The sweat test must be performed. The genetic test for the CFTR mutation panel. Within the clinical conditions: culture of sputum secretions with typical germs associated with the pathology, evaluation of exocrine pancreatic function and spermogram in adult men $[13,14]$. Diagnosis requires a positive sweat test or clinical characteristics suggestive of CF (Table 1), which include but are not restricted to diffuse bronchiectasis, positive cultures of CF-associated pathogens (especially Pseudomonas aeruginosa), 
Table 1: Clinical characteristics suggestive of CF.

Diffuse bronchiectasis

Positive cultures of CF-associated pathogens (especially Pseudomonas aeruginosa)

Exocrine pancreatic insufficiency

Salt wasting syndrome

Obstructive azoospermia in men

exocrine pancreatic insufficiency, salt wasting syndrome, obstructive azoospermia in men, and sweat test $>59 \mathrm{mmol} / \mathrm{L}$ and / or two mutations causing CFTR mutations in trans. The term mutation refers to the pathogenic variants described in CFTR2 (http://www.cftr2.org) [14].

In ranges of 30-59 mmol / $\mathrm{L}$, borderline, the sweat test should be repeated and referred to a specialized center for an extensive study of CFTR genes [14]. In intermediate cases of sweat test, other electrophysiological studies can be performed: differential of nasal potential and measurement of intestinal transepithelial electrical property [14].

Defects in the CFTR lead to lung disease characterized by obstruction, persistent bacterial infection, and neutrophilic infiltration. The inflammatory response escapes from homeostatic control, is excessive and causes damage to the tissue itself. It is associated with greater bacterial adherence and inflammatory response affecting the complex signal process. Given the excessive number of mediators and damaging effects of the inflammatory response, the inhibition of a single mediator does not produce significant impacts on the pathology of the disease. As inflammation occurs early in life, it contributes to the progress of structural damage in the airway, and it is easier to modify it before it becomes more severe. The basic defect in CF leads to failure of mucociliary clearance, impacts mucous membranes and secondary infection with pathogens such as Staphylococcus aureus and Pseudomona aeruginosa. Chronic infection causes acute exacerbations to prevent lung function from returning to baseline levels [14].

Epithelial cells in the pancreatic and biliary ducts are also affected by CFTR dysfunction. Mucus obstruction occurs early in utero and most individuals with severe mutations have pancreatic insufficiency at birth and soon after. This is caused by a chronic obstructive pancreatitis. By contrast, individuals with class IV, V, or VI mutations are often pancreatic sufficient at birth, although some develop pancreatic insufficiency later in life. Pancreatic insufficiency can be treated with pancreatic enzyme replacement therapy. Careful titration of dose with matched energy intake is important in the dietary management of pancreatic insufficiency. All cystic fibrosis multidisciplinary teams should have specialist dietetic support to manage the nutritional consequences of pancreatic insufficiency and increased metabolic rate. ${ }^{6}$ Table 2 lists the most common gastrointestinal problems [4]. The progression of the disease is characterized by periods of stability interspersed with intermittent episodes of clinical deterioration, called pulmonary exacerbations [14]. There is no definition of "exacerbations" but it is essential that they are recognized and treated as soon as possible. Patients in whom they experience changes in their symptoms that may represent an exacerbation should access a specialized center without delay [14]. Treatments of exacerbations may require oral or intravenous antibiotics and it is important not to delay their administration [14]. Care by a multidisciplinary team is essential (Table 3), because not only will antibiotics be required, but also, for example, having a lower appetite will require a higher caloric intake; for these reasons it is necessary to control it by nutritionists or gastroenterologists. Usually endovenous treatment is performed for 14 days but in some cases it is required to prolong it for 14 days and can even be performed at home so that they can continue with their activities.

Table 2: Gastrointestinal problems

\begin{tabular}{|c|c|}
\hline Pancreas & $\begin{array}{l}\text { Exocrine insufficiency ( } 85-90 \% \text { of newborns): malabsorption, } \\
\text { steatorrhoea, poor growth } \\
\text { Pancreatitis }\end{array}$ \\
\hline Oesophagus & Gastro-oesophageal reflux \\
\hline Small bowel & $\begin{array}{c}\text { Meconium ileus } \\
\text { Distal intestinal obstruction syndrome } \\
\text { Coeliac disease; malabsorption despite adequate enzymes }\end{array}$ \\
\hline Colon & Constipation \\
\hline Rectum & Rectal prolapse \\
\hline Liver & $\begin{array}{l}\text { Fatty liver (usually not symptomatic); cirrhosis (variceal bleeding, } \\
\text { hypersplenism) }\end{array}$ \\
\hline
\end{tabular}

Table 3: Multidisciplinary team.

Internal medicine

Gastroenterology and hepatology

$$
\begin{aligned}
& \text { Physiotherapists } \\
& \text { Specialist nurses }
\end{aligned}
$$

Dietitians

Psychologists

Social workers

Pharmacists

Secretarial support

Diabetes / endocrinology

Pulmonology

\section{References}

1. Fraser R, Colman N, Müller NL, Paré PD (2006) Fundamentos de las enfermedades del tórax. Tercera Edición. Editorial Masson, 676-680. Link: https://bit.ly/3jxL1dl

2. Elston C, Simmonds N, Geddes D (2007) The future for a child born with Cystic Fibrosis today. Breathe 4: 16-23. Link: https://bit.ly/34umZvu

3. Ribeiro LV, Silva Filho F, Castaños C, Ruíz HH (2016) Cystic fibrosis in Latin America-Improving the awareness. J Cyst Fibros 15: 791-793. Link: https://bit.ly/2Hwh40y

4. Davies J, Alton E, Bush A (2007) Cystic Fibrosis. Br Med J 335: 1255-1260. Link: https://bit.ly/35Bm3oG

5. Solomon G, Marshall S, Ramsey B, Rowe S (2015) Breakthrough Therapies: Cystic Fibrosis (CF) Potentiators and Correctors. Pediatr Pulmonol 15: S3-13. Link: https://bit.ly/3opQION 
6. Elborn S (2016) Cystic fibrosis. Lancet 16: 1-13. Link: https://bit.ly/3ouqnyz

7. Conrad DJ (2005) Manual of Clinical Problems in Pulmonary Medicine. Sixth Edition. Editorial Lippincott Williams \& Wilkins 417-423.

8. Segal E, Fernandez A, Fernado R (2004) Fibrosis Quística. Link: https://bit.ly/3ovkvFj

9. Davies JC, Ebdon A, Orchard C (2014) Recent Advances in the Management of Cystic Fibrosis. Arch Dis Child 11: 1033-1036. Link: https://bit.ly/3juUq5I

10. Bush A, Alton EWFW, Davies JC, Griesenbach U, Jaffe A (2006) Cystic Fibrosis in the 21st Century. Progress in Respiratory Research 34: 187-195. Link: https://bit.ly/310VmvE
11. Milla C (2007) Nutrition and Lung Disease in Cystic Fibrosis. Clin Chest Med 28: 319-330. Link: https://bit.ly/3kz2Utw

12. Sawicki G, Goss C (2015) Tackling the Increasing Complexity of CF Care Pediatric Pulmonol 15: S74- S79. Link: https://bit.ly/35J9hoe

13. Nick J, Rodman D (2005) Manifestation of Cystic Fibrosis diagnosed in adulthood. Curr Opin Pulm Med 11: 513-518. Link: https://bit.ly/322WPP9

14. Castellani C, Duff A, Bell SC, Heijerman HGM, Munck A, et al. (2018) ECFS best practice guidelines: the 2018 revision. J Cyst Fibros 17: 153-178. Link: https://bit.ly/3jwIW2s

\section{Discover a bigger Impact and Visibility of your article publication with}

\section{Peertechz Publications}

\section{Highlights}

* Signatory publisher of ORCID

* Signatory Publisher of DORA (San Francisco Declaration on Research Assessment)

* Articles archived in worlds' renowned service providers such as Portico, CNKI, AGRIS, TDNet, Base (Bielefeld University Library), CrossRef, Scilit, J-Gate etc.

* Journals indexed in ICMJE, SHERPA/ROMEO, Google Scholar etc.

* OAI-PMH (Open Archives Initiative Protocol for Metadata Harvesting)

* Dedicated Editorial Board for every journal

* Accurate and rapid peer-review process

* Increased citations of published articles through promotions

* Reduced timeline for article publication

Submit your articles and experience a new surge in publication services (https://www.peertechz.com/submission).

Peertechz journals wishes everlasting success in your every endeavours

Copyright: (C) 2020 Baran E. This is an open-access article distributed under the terms of the Creative Commons Attribution License, which permits unrestricted use, distribution, and reproduction in any medium, provided the original author and source are credited. 